\title{
FAKTOR-FAKTOR YANG BERHUBUNGAN DENGAN ASMA BRONCIAL PADA ANAK DI RUANG SAKURA RUMAH SAKIT PTPN II BANGKATAN BINJAI TAHUN 2017
}

\author{
Factors Related to Broncial Asthma in Children in Sakura Space Hospital \\ of PTPN II Bangkatan Binjai In 2017
}

\author{
Sri Wahyuni ${ }^{1}$ \\ ${ }^{1}$ Dosen Akademi Keperawatan Sehat Binjai \\ E-mail: sriwahyunimiko@yahoo.co.id
}

\begin{abstract}
Abstrak
Asma broncial merupakan penyakit kronik yang sering dijumpai pada anak maupun dewasa di negara berkembang maupun negara maju. Sejak dua dekade terakhir, dilaporkan bahwa prevalensi total asma broncial di dunia diperkirakan 7,2\% (6\% pada dewasa dan $10 \%$ pada anak). Prevalensi tersebut sangat bervariasi pada tiap negara dan bahkan perbedaan juga didapat antar daerah di dalam suatu negara. Prevalensi asma broncial di berbagai negara sulit dibandingkan, tidak jelas apakah perbedaan angka tersebut timbul karena adanya perbedaan kriteria diagnosis atau karena benar-benar terdapat perbedaan. Penelitian ini bersifat deskriptif untuk mengetahui faktor-faktor yang berhubungan dengan asma broncial pada anak di ruang sakura rumah sakit PTPN II Bangkatan Binjai tahun 2017. Pengumpulan data dalam penelitian ini menggunakan kuesioner yang dikelompokan berdasarkan alergi, asap rokok, olahraga, dan polusi udara hasil penelitian ini menunjukkan bahwa dari 20 responden (100\%) diketahui bahwa 5 orang (25\%) karena faktor alergi, 5 orang $(25 \%)$ karena asap rokok, 4 orang $(20 \%)$ karena olahraga dan 6 orang $(30 \%)$ karena polusi udara. Diharapkan pihak Rumah akit Untuk selalu meningkatkan penyuluhan kepada pasien tentang penyakit asma broncial pada anak.
\end{abstract}

Kata Kunci: Faktor-Faktor Asma Broncial

\begin{abstract}
Broncial asthma is a chronic disease that is often found in children and adults in developing and developed countries. Since the last two decades, it has been reported that the total prevalence of bronchial asthma in the world is estimated to be $7.2 \%$ (6\% in adults and $10 \%$ in children). The prevalence varies greatly by country and even differences are also found between regions within a country. The prevalence of bronchial asthma in various countries is difficult to compare, it is not clear whether the difference in numbers arises because of differences in diagnostic criteria or because there really are differences. This study is descriptive to determine the factors associated with bronchial asthma in children in the Sakura room of PTPN II Bangkat Binjai Hospital in 2017. Data collection in this study using questionnaires grouped based on allergies, cigarette smoke, sports, and air pollution from research results This shows that from 20 respondents (100\%) it was known that 5 people $(25 \%)$ were due to allergic factors, 5 people $(25 \%)$ because of cigarette smoke, 4 people $(20 \%)$ because of sports and 6 people $(30 \%)$ due to air pollution . It is expected that the Rumah Akit will always increase counseling to patients about bronchial asthma in children.
\end{abstract}

Keywords: broncial asthma factors

\section{PENDAHULUAN}

Asma broncial merupakan penyakit kronik yang sering dijumpai pada anak maupun dewasa di negara berkembang maupun negara maju. Sejak dua dekade terakhir, dilaporkan bahwa prevalensi total asma broncial di dunia diperkirakan $7,2 \%$ (6\% pada dewasa dan $10 \%$ pada anak). Prevalensi tersebut sangat bervariasi pada tiap negara dan bahkan perbedaan juga didapat antar daerah di dalam suatu negara. Prevalensi asma broncial di berbagai negara sulit dibandingkan, tidak jelas apakah perbedaan angka tersebut timbul karena adanya perbedaan kriteria diagnosis atau 
karena benar-benar terdapat perbedaan (IDAI, 2014).

Sebenarnya asma broncial bukan termasuk penyakit yang mematikan, namun mordibitas dan mortalitas asma broncial relatif meningkat tiap tahunnya, menurut perkiraan WHO, sekitar 300 juta orang menderita asma broncial dan 255 ribu orang meninggal karena asma broncial didunia pada tahun 2005 dan angka ini masih terus meningkat. Dilaporkan pada bahwa tahun 1994 sekitar 5500 pasien asma broncial meninggal di Amerika. Angka kematian pada setiap kelompok usia meningkat pada tahun 1980-1995. Kematian akibat asma broncial pada semua usia meningkat 3,4\% tiap tahun, sejak tahun 1980-1998. Kematian mencapai 3,8 per 1 juta anak pada tahun 1997, dan meningkat kembali 3,5 per 1 juta anak pada tahun 1998. Berdasarkan laporan NCHS pada tahun 2000, terdapat 4487 kematian akibat penyakit asma broncial atau 1,6 per 100.000 populasi (NCHS, 2014).

Jumlah penderita asma broncial di indonesia pada tahun 2002 sebanyak 12,5 juta orang, penyakit asma broncial juga masuk dalam sepuluh besar penyakit penyebab kesakitan dan kematian di indonesia. Survey kesehatan rumah tangga tahun 2005 mencatat 225.000 orang meninggal karena asma broncial. Menurut riset kesehatan dasar tahun 2007 secara keseluruhan prevalensi penderita asma broncial di indonesia sebesar 3,5\% dan data riset kesehatan dasar di tahun 2013 penderita asma broncial meningkat menjadi 4,5\% (Kemenkes, RI, 2015).

Hasil Riset Kesehatan Dasar tahun 2007 menunjukan bahwa prevalensi asma broncial di provinsi sumatra utara adalah 3\% dengan kisaran prevalensi sebesar 3-6,4\%. Kabupaten dengan prevalensi asma broncial tertinggi adalah Kabupaten Mandailing Natal. Di kota Medan, prevalensi asma broncial mecapai 3,6\% (laki-laki 1,9\% dan perempuan 1,7\%) (Depkes, RI, 2015).

Pada bulan Januari - Mei 2017
peneliti menemukan asma broncial

sebanyak 25 orang pasien. didapat faktorfaktor yang berhubunggan dengan asma broncial, karna adanya alergi, asap rokok, olahraga, polusi udara. Hal ini ditentukan oleh adanya riwayat gejala gangguan pernafasan seperti mengi nafas, terengahengah, dada terasa berat/tertekan, dan batuk, yang berfariasi waktu dan intensitasnya, diikuti dengan keterbatasan aliran udara ekspirasi yang bervariasi. (Data RS. PTPN II Bangkatan, 2017).

Berdasarkan data diatas peneliti tertarik untuk mengetahui fakto-faktor yang berhubungan dengan asma broncial di RS. PTPN II Bangkatan Binjai Tahun 2017.

\section{METODE}

Jenis penelitian yang dilakukan adalah deskriptif yaitu metode penelitian yang di lakukan terhadap sekumpulan objek yang biasanya bertujuan untuk melihat gambaran fenomena (termasuk kesehatan) yang terjadi dalam suatu populasi tertentu (Notoatmojdo, 2010). Penelitian ini dimulai dari bulan Januari s.d Juni 2017. Populasi adalah keseluruan objek penelitian yang akan diteliti(Hidayat, 2014). Dalam penelitian ini populasinya adalah semua pasien anak yang menderita asma bronkial di RS PTPN II Bangkatan Binjai sebanyak 30 orang. Sampel adalah sebagian dari keseluruhan objek yang diteliti dan dianggap mewakili seluruh populasi (Notoatmodjo, 2010). Teknik pengambilan sampel dalam penelitian ini adalah menggunakan total sampling yaitu sebanyak 30 orang. Pengumpulan data menggunakan kuesioner. Penglohan data melalui tahap editing, coding, sorting, dan mengeluarkan informasi. Analisa data yang digunakan dalam penelitian ini adalah analisis univariate (analisis deskriptif).

\section{HASIL PENELITIAN \\ Karakteristik Responden}

Responden penelitian ini didistribusikan berdasarkan jenis kelamin dan umur yang dapat dilihat pada tabel berikut ini: 
Tabel 1. Distribusi Responden Berdasarkan Jenis Kelamin di RS PTPN II Bangkatan Binjai Tahun 2017

\begin{tabular}{c|c|c|c}
\hline No & Jenis Kelamin & Jumlah & Persentase (\%) \\
& & 20 & $66,6 \%$ \\
1 & Laki-laki & 10 & $33,4 \%$ \\
\hline \multicolumn{2}{|c|}{ Jumlah } & $\mathbf{3 0}$ & $\mathbf{1 0 0 \%}$ \\
\hline
\end{tabular}

Dari tabel 1. dapat di lihat bahwa responden memiliki jenis kelamin laki-laki sebanyak 20 orang $(66,6 \%)$ dan jenis kelamin perempuan 10 orang $(33,4 \%)$.

Tabel 2. Distribusi Responden Berdasarkan Kelompok Umur di Rumah Sakit PTPN II Bangkatan Binjai Tahun 2017

\begin{tabular}{c|c|c|c}
\hline No & $\begin{array}{c}\text { Kelompok Umur } \\
\text { (Tahun) }\end{array}$ & Jumlah & Persentase (\%) \\
\hline 1 & 30-31 Tahun & 10 & $33,33(\%)$ \\
2 & 32-33 Tahun & 10 & $33,33(\%)$ \\
3 & 34-35 Tahun & 10 & $33,33(\%)$ \\
\hline \multicolumn{2}{l}{} \\
\hline
\end{tabular}

Dari 30 responden di peroleh bahwa usia 30-31 tahun 10 orang $(33,33 \%)$, usia 32-33 tahun 10 orang $(33,33 \%)$ dan usia 34-35 tahun 10 orang $(33,33 \%)$.

Tabel 3. Distribusi Diagram Berdasarkan Faktor-Faktor Yang Berhubungan Dengan Asma Broncial Pada Anak

\begin{tabular}{c|c|c|c|c|c}
\hline \multirow{2}{*}{ No } & \multicolumn{6}{|c|}{ Faktor-Faktor Yang Berhubungan Dengan Asma Broncial } & Persentasi \\
\cline { 2 - 5 } & Alergi & Asap Rokok & Olahraga & Polusi Udara & $(\boldsymbol{\%})$ \\
\hline 1 & 6 & - & - & - & $20 \%$ \\
2 & - & 9 & - & - & $30 \%$ \\
3 & - & - & 5 & - & $16,6 \%$ \\
4 & - & - & - & 10 & $33,4 \%$ \\
\hline \multicolumn{6}{c}{ Jumlah } \\
\hline
\end{tabular}

Dari tabel diatas dapat di lihat berdasarkan faktor-faktor yang berhubungan dengan asma broncial yaitu foktor alergi sebanyak 6 orang (20\%), faktor asap rokok sebanyak 9 orang (30\%), faktor olahraga sebanyak 5 orang $(16,6 \%)$, dan polusi udara sebanyak 10 orang $(33,4 \%)$. 


\section{PEMBAHASAN}

Dalam penelitian ini peneliti ingin membahas tentang hal-hal yang berkaitan dengan tujuan penelitian seperti yang telah di kemukakan pada bagian pendahuluan bahwa tujuan umum dari penelitian ini adalah untuk mengetahui faktor-faktor yang berhubungan dengan asma broncial pada anak di ruang sakura Rumah Sakit PTPN II Bangkatan Binjai Tahun 2017.

Berdasarkan hasil penelitian faktorfaktor yang berhubungan dengan asma broncial dapat di lihat bahwa dari 30 responden berdasarkan jenis kelamin, lakilaki 20 orang $(66,6 \%)$ dan perempuan 10 orang $(33,4 \%)$. Jadi berdasarkan umur faktor-faktor yang berhubungan dengan terjadinya asma broncial tertinggi pada jenis kelamin laki-laki.

Berdasarkan hasil

penelitian faktor-faktor yang berhubungan dengan asma broncial dapat di lihat dari 30 responden berdasarkan umur di jumpai pada penderita asma broncial yang paling banyak adalah umur antara 30-31 tahun terdapat 10 orang $(33,33 \%)$, umur $32-33$ tahun terdapat 10 orang $(33,33 \%)$. Dan umur 34-35 tahun terdapat 10 orang $(33,33 \%)$.

Berdasarkan hasil penelitian faktorfaktor yang berhubungan dengan asma broncial berdasarkan hasil kuesioner bahwa dari 30 responden faktor yang berhubungan dengan asma oleh faktor alergi 6 orang (20\%), faktor asap rokok 9 orang (30\%), faktor olahraga 5 orang $(16,6 \%)$ dan polusi udara 10 orang $(33,4 \%)$, jadi di ketahui bahwa dari 30 responden penderita penyakit asma broncial yang lebih dominan adalah dari faktor polusi udara dengan jumlah 10 orang $(33,4 \%)$. hal ini karena uap senyawa organik dalam ruangan, kualitas udara buruk dari polusi kendaraan atau kadar ozon yang tinggi. Menurut (World Bank 2014). Polusi udara sebagian besar dipenggaruhi oleh kendaraan bermotor yang menghasilkan emisi gas buang yang buruk dan asap pabrik.

\section{KESIMPULAN}

Berdasarkan hasil penelitian, maka dapat disimpulkan bahwa : a. Penelitian ini dapat dilakukan dengan baik berkat adanya kerjasama yang baik dari berbagai pihak.

b. Penelitian pada tinjauan faktor-faktor yang berhubungan dengan terjadinya asma broncial pada orang dewasa yang dominan di sebabkan oleh polusi udara yaitu dari 30 responden ada sebanyak 10 orang $(33,4 \%)$.

c. Penelitian pada tinjauan faktor-faktor yang berhubungan dengan terjadinya asma broncial pada anak yang tidak dominan yaitu oleh faktor alergi sebanyak 6 orang (20\%), asap rokok sebanyak 9 orang $(30 \%)$, dan olahraga sebanyak 5 orang $(16,6 \%)$.

d. Berdasarkan umur diketahui bahwa kelompok antara 30-31 tahun ada 10 orang (33,33\%), 32-33 tahun ada 10 orang $(33,33 \%)$ dan $34-35$ tahun ada 10 orang $(33,33 \%)$. Jadi jumlah seluruhnya dari 30-35 tahun yang menderita asma broncial yaitu sama.

e. Berdasarkan jenis kelamin di ketahui bahwa laki-laki 20 orang $(66,6 \%)$ yang paling banyak menderita asma broncial.

\section{SARAN}

Adapun saran dalam penelitian ini adalah:

a. Bagi Responden

Untuk mencari informasi yang dapat menambah pengetahuan tentang faktorfaktor yang berhubungan dengan asma broncial.

b. Bagi Rumah Sakit

Untuk selalu meningkatkan penyuluha kepada pasien tentang penyakit asma broncial.

c. Bagi pendidikan

Untuk menambah bahan bacaan dan referensi khususnya tentang penyakit asma broncial.

\section{DAFTAR PUSTAKA}

Arikunto, Suharsimi, 2013. Prosedur Penelitian : Suatu Pendekatan Praktek, Jakarta : Rineka Cipta.

Baratawidjaja, K, 1990. Asma broncial, dikutip dari ilmu penyakit dalam. Jakarta : FK UI

Departemen Kesehatan Republik Indonesia, 2007. Riset Kesehatan Dasar Indonesia 
Tahun 2013. Jakarta : Badan Penelitian dan Pengembangan Kesehatan Departemen Kesehatan RI.

Hidayat, A. Aziz Alimul, 2013. Metode Penelitian Keperawatan dan Teknik Analisis Data, Jakarta : Salemba Medika

Marni., S.Kep., Ns., M.Kes, 2014. Asuhan keperawatan pada anak sakit dengan gangguan pernapasan. Yogyakarta : Gosyen Publishing

Notoatmodjo, Soekidjo, 2010. Metodologi Penelitian Kesehatan., Jakarta : Rineka Cipta. 